\title{
Handcarts Across Iowa: Trial Runs for the Willie, Haven, and Martin Handcart Companies
}

\author{
LYNDIA MCDOWELL CARTER
}

FOR THE ROUGHLY 1,100 HANDCART EMIGRANTS camping in July 1856 at the Mormon outfitting campground near Iowa City, waiting to start their long walk to the Missouri River, where they would be resupplied for crossing the Plains to the Salt Lake Valley in Utah Territory, delays were frustrating. Three handcart groups had left before them in June. ${ }^{1}$ The season for safe traveling was growing late, and the migrants were anxious to be on their way to complete the journey to Zion that they had begun weeks earlier when they left Liverpool and Copenhagen. The immigrants from the ship Thornton had arrived at the camp on June 26; the ones from the ship Horizon arrived on July $8 .{ }^{2}$ Both groups of "Saints," members of the Church of

1. Six Mormon handcart companies, consisting of approximately 2,000 persons, outfitted and left the Iowa City area in the summer of 1856 . The first three began their journey west in June, with sufficient time to arrive in the Salt Lake Valley before the onset of winter. Those first three companies were captained by, respectively, Edmund Ellsworth, Daniel D. McArthur, and Edward Bunker. All six handcart companies that summer of 1856 had similar experiences and hardships crossing Iowa. For a good overview of the Mormon handcart migration, see LeRoy R. Hafen and Ann W. Hafen, Handcarts to Zion: The Story of a Unique Western Migration, 1856-1860 (Glendale, CA, 1960).

2. The Willie company comprised approximately 500 emigrants, most of them passengers from the Thornton. More than 600 persons, the vast majority of whom were passengers from the Horizon, made up the Martin company, which arrived at the railroad depot in Iowa City on July 8, 1856.

THE ANNALS OF IOWA 65 (Spring/Summer 2006). (C) The State Historical Society of Iowa, 2006. 
Jesus Christ of Latter-day Saints, had to wait for their handcarts to be finished and other arrangements to be completed before they could leave for the West. Because of the delays, the members of these companies would suffer greatly when they were caught in blizzards in present-day Wyoming three months later.

The emigrants looked eagerly toward their start. In their enthusiasm to be on the road, they could not possibly have imagined the challenges they would face when actually under way. Approximately 270 miles lay between the Iowa City camp and the Missouri River. Covering that distance by foot with handcarts would take nearly a month. That leg of their journey across Iowa's prairie roads provided a test run for the handcart emigrants, giving them a sampling of the thousand miles that stretched ahead of them from the Missouri River to Salt Lake City.

Once undertaken, the Iowa portion of the trek would prove to be a time of weeding out the sick, the weak, and the fainthearted. For those who demonstrated their mettle and their good health by sticking it out, the long Iowa phase of their journey west would build muscle, endurance, and stamina. During the four weeks, minus a few days, it would take the Willie, Haven, and Martin handcart companies to walk across Iowa pushing and pulling their handcarts, the migrants would learn skills they would need for life on the road. Bare feet would become toughened, exposed skin would turn leathery with sunburn, and bodies would grow accustomed to the relentless heat, the choking dust, the sudden thunderstorms, the cruel humidity, and the strains of uphill tugging and downhill braking. They would learn that they could travel no farther by day's end than the oxen that pulled their few supply wagons. They would fight sickness and weariness, sometimes extreme exhaustion. They would be hungry on the scanty food rations. ${ }^{3}$ They would find

3. The handcart plan was designed to provide for the largest possible number of emigrating church members at the lowest possible cost, so the emigrating agents established a very stringent budget. Thus, the provisions for the handcart companies were kept to a bare minimum. The scant provisions caused many of the travelers in all six companies to feel hungry much of the time. In Iowa the provisions were especially limited. Because the handcart companies would be passing through towns and past farms, it was likely expected that the migrants would purchase supplemental foodstuffs from the local populace. 
out the hard way that pulling loaded carts was arduous labor and that the daily routine was tedious. But while waiting at the outfitting camp, they felt excited, perhaps a bit nervous, and eager to be on their way. During the days in the last half of July and through August, the members of these last three handcart companies of 1856 would discover by experience, as had the three handcart companies that preceded them that summer, that the journey, this trial by handcart, was not going to be easy. However, they firmly believed that God would try His people, and so they would accept their lot and resolutely trudge the long, hot miles across Iowa.

WHEN AT LAST each of these three groups received the word that they would roll out on the morrow, the emigrants felt the sheer joy of finally being able to leave the Iowa campground and start on their way. Of the three groups, the Willie company set out first. On Tuesday, July 15, amid beautiful but very warm weather, the members of the handcart company led by Captain James G. Willie busily made last-minute arrangements for their start toward Zion. The 500 emigrants under Willie's command loaded their carts. Each of the 100 two-wheeled vehicles contained a mere 17 pounds of baggage for each of the five persons assigned to it, along with some provisions and cooking utensils.

Church agents at the campground organized the emigrants into groups of 20, who at night would occupy a tent together and be supervised by a tent captain. Five men-Millen Atwood, Levi Savage, William Woodward, John Chislett, and Johan Ahmanson-commanded divisions called "hundreds"; each took responsibility for the people of five tents (about 100 people). These five captains of hundreds were accountable directly to Captain Willie, enforced his orders, saw to the safety and well being of their 100 people, and supervised the 20 carts their people used and the five company wagons that carried the supplies and sick people. Edward Griffiths served as the Willie company's commissary, and William Read worked as the camp butcher. All adult men and teenaged boys were required to take turns serving

However, because many members of the handcart companies were poor, purchasing extra provisions was not an option they could afford, so many had to make do with the rations the agents at the Iowa City camp had provided. 
guard and herd duties at night, with a captain of the guard to see that all guard duties were performed nightly. This organizational structure maintained discipline and order, as well as spread the responsibility evenly.

When everything was at last ready and all the carts loaded and in proper marching order, the Willie company "pulled up stakes" and rolled out of camp the afternoon of July 15. The first day's move covered but a short distance to a fresh campsite. In high spirits, the migrants set their tents, unloaded their bedding, and went about their evening chores. This dress rehearsal, of sorts, passed off successfully and let the migrants know what to expect when the real trek began. ${ }^{4}$

On July 16, the oxen, only somewhat tame and insufficiently trained, delayed the Willie company's start until late afternoon. Then the handcarts rolled just three miles. The oxen that pulled four of the five provision wagons behaved rather wildly and proved troublesome for their drivers. The driver of the mules pulling the fifth wagon also had a hard time with his unruly team. The wagons did not make it to camp until two or three hours after the migrants with their handcarts. A road full of

4. I have created the following synopses for each day that the Willie Handcart company traveled through Iowa by combining information from the diaries and journals of the participants who kept records as they journeyed: James G. Willie Emigrating Company, Journal (the identity of the clerk across Iowa is not known), typescript, Church of Jesus Christ of Latter-day Saints Department of Family and Church History (hereafter cited as LDS Church Archives), Salt Lake City; Levi M. Savage Jr., Journals, holograph, L. Tom Perry Special Collections, Harold B. Lee Library, Brigham Young University (hereafter BYU Library), Provo, Utah; William Woodward, Private Journal, 1855-1857, in William Woodward Papers, LDS Church Archives; Alfred Gadd, typescript, in Biographies of Utah County Pioneers 28 (June 1940), 82-88, in the Daughters of Utah Pioneers Museum, Provo, Utah; Peter Madsen, Diary, 4/23/1856-9/8/ 1856, copy of transcription and translation from Danish by Don H. Smith, LDS Church Archives. Supplementing these contemporary daily records written during the trek, are the following reminiscences or memoirs: John Chislett, "Narrative," in T. B. H. Stenhouse, Rocky Mountain Saints: A Full and Complete History of the Mormons (New York, 1873), 314-16; Johan Ahmanson, Vors tid Muhmed (Secret History), trans. Gleason L. Archer (Chicago, 1984), 27-36; James G. Willie, "Synopsis of the 4th Handcart Company's trip from Liverpool, England, to Great Salt Lake City, in the Spring, Summer and Autumn of 1856," holograph, LDS Church Archives (typescript copy also available in LDS Journal History, 11/9/1856, LDS Church Archives); George Cunningham, Autobiography, 1876, typescript, LDS Church Archives. 
holes and poorly constructed and badly maintained bridges offered additional challenges.

The next day, the company did not travel. That night Captain Willie passed on instructions from Daniel Spencer, leader at the Iowa City outfitting camp, that they could "not move off this ground, until the spirit of mermering, if there was any, Seased amoung the Saints of this Camp." 5

On July 18, a bugle roused the people from their beds at 4 a.m. The emigrants received their daily provisions of ten ounces of flour, a little sugar, rice, dried apples, salt, and a little bit of pork. Then at 11 a.m., the company pulled out. Despite their enthusiasm, the day's walk of six to eight miles tested their ardor. The afternoon was hot and the roads were terrible. Clouds of dust thrown up by hundreds of tramping feet and the turning cart wheels enveloped the migrants.

A bracingly cold morning on July 19 transformed into a hot day as the hours and miles fell behind the travelers. Although the road was much improved, lugging the carts proved to be extremely hard work. Levi Savage recorded in his diary, "Some of the Saints both olde and young, were nearly overcome yet they endured much better than could be expected." 6 After more than nine hours of travel covering 12 miles, the fatigued company set up evening camp. William Woodward unloaded the mule-drawn wagon of its passengers and supplies and went back three miles to haul in sick people who had given out on the way. Adelaide Baker decided to give up the journey to Zion and left the company. Although the area through which they passed was thinly populated, one resident boasted that he would bring others and tear down all their tents; fortunately it was only an idle threat.

The next day the company rested for the Sabbath. Adelaide Baker returned to get two of her children. Three other women also abandoned the journey because of the hardships of handcart travel. ${ }^{7}$ Some curious local inhabitants visited the camp.

5. Savage, Journal, 7/17/1856.

6. Ibid., 7/19/1856.

7. Ibid., 7/21/1856. Savage identifies the three women as Mrs. Smith and the two Miss Birds. According to the Church of Jesus Christ of Latter-day Saints British Mission Emigration Records in the LDS Church Archives, Ann Bird's age was 20 years, her sister Sabina was 17, and Harriet Smith was 27 years old. 
Some of the visitors seemed belligerent and quarrelsome, seemingly looking for trouble. Camp leaders spoke at an afternoon worship service and told the visitors about Mormon beliefs and their commitment to obey what they believed to be God's commandments regardless of the consequences. After these leaders explained to the intruders the Mormons' right to worship as they wished, the strangers behaved in a "perfectly docile" manner and returned to their homes without further incident.

The Sunday rest made Monday's journey more pleasant. Everyone seemed cheerful, and only one sick person started the day by riding in the mule-drawn ambulance wagon. Health seemed much improved. The morning went well. But as the day heated up, a few of the travelers grew ill. Because they were only three miles from Marengo, William Woodward went there to purchase brandy and whiskey to use as medicine to revive the sick. Also because they were near town, curious and troublesome local residents visited the camp. Seven rowdy young fellows came to camp intent on making trouble. They cursed, swore, hollered, and used vulgar language, disturbing the handcart migrants. Captain Willie stationed extra armed guards. Apparently this "warm reception," in Savage's words, discouraged the ruffians, who soon left.

On Tuesday, July 22, the Willie company took advantage of the cool morning and walked four hours before resting. Then they moved over hilly, dusty roads. During the day, as the emigrants trudged ten miles, the heat became extreme and oppressive. "Nearly all beat out," they stopped at "Bear Creek" in the early afternoon. ${ }^{8}$ Several strangers, curious but friendly, visited the camp, but caused no problems.

The Charles Peat family called it quits the next morning. Because their handcart was church property, it stayed with the company when they left. 9 The morning was hot and sultry, with not a breath of a breeze. The company tramped for five miles before stopping for a rest. On the move again, the walkers tugged their carts another five miles. Despite the heat, Levi

8. Willie Company, Journal, 7/22/1856.

9. Charles Peat, his wife, Martha, and their four children dropped out for personal reasons not explained by the company clerk in the Willie Company Journal. 
Savage noted that "the weak are getting strong, the lame, and aged, get along exceedingly well." 10 However, one of the wagon drivers picked up Mary Williams insensible on the side of the road. Possibly she had suffered sunstroke, but some of her companions thought she had collapsed because she had eaten a large amount of wild green plums and crabapples. The division captains had a difficult time keeping the long, strungout handcart train in order. Many cart pullers tried to pass slower cart teams, and some carts failed to keep up the pace and lagged behind. In the afternoon, the company took another rest stop to avoid walking farther in the tremendous heat. At about six o'clock, the company rolled forward again and made another three miles, making a total of 13 for the day. When they stopped, "a great many" were "sick \& tired out," according to the company clerk, but Savage noted that their spirits remained high. However, Mary Williams, a 50-year-old emigrant from Worcester, England, was dead.

On July 24, the handcart migrants moved just two miles and then encamped in the woods for the remainder of an intensely hot day. The region was farmed, but sparsely settled. The locals were generally friendly and generous to the Mormons. Some gave the handcart travelers milk or sold them flour at a low price. Savage remarked that although most of the residents were generally kind, a few were antagonistic. With a community nearby, company members were able to obtain lumber and make a coffin for Mary Williams. They laid her to rest in the local cemetery, which was about a mile from the handcart camp.

Company members began to complain about their short rations. ${ }^{11}$ Some of the travelers who had money or items for trade purchased food from local merchants or farmers; others begged; a few even stole to assuage their hunger. Hunger was making some ill. Peter Madsen, a member of the Danish "hundred" (made up almost entirely of immigrants from Denmark), noted that Captain Willie scolded the English whose hunger

\section{Savage, Journal, 7/23/1856.}

11. Levi Savage specified the precise amounts of their rations: ten ounces of flour per day per adult; ten ounces of pork per person each 28 days; and small rations of rice, apples, sugar, tea, and coffee. Judging this insufficient for their needs, he commented, “It is not enough." Savage, Journal, 7/24/1856. 
drove them to milk the farmers' cows or kill their pigs. Perhaps hunger, heat, and hard work caused some dissension and grumbling to creep in, because in meeting that evening Willie and sub-captains Atwood and Woodward counseled the people to be united. Two decades later, John Chislett recalled the hungry journey across Iowa:

Our rations consisted of ten ounces of flour to each adult per day and half that amount to children under eight years of age. Besides our flour we had occasionally a little rice, sugar, coffee, and bacon. But these items (especially the last) were so small and infrequent that they scarcely deserve mentioning. Any hearty man could eat his daily allowance for breakfast. In fact, some of our men did this, and then worked all day without dinner, and went to bed supperless or begged food at the farmhouses as we travelled along.

Chislett noted the kindness of the people of Iowa. He remarked that large numbers of Iowans came to the handcart camp whenever the Willie company stopped near a settlement, and they "were very good in giving to those who asked food, expressing their sympathy for us whenever they visited our camp." Whether motivated by concern or prejudice, some locals "tried to dissuade" them from traveling to Salt Lake by handcart; some offered employment and housing. "A few of our company left us from time to time; but the elders constantly warned us against 'the Gentile,' and by close watching succeeded in keeping the company tolerably complete," Chislett remembered. Meetings occurred nearly every evening for counsel, prayer, and preaching, the main theme of which was "'obey your leaders in all things.'" In retrospect, Chislett felt some bitterness against those who sent them on their journey with such limited provisions. "I do not know who settled the amount of our ration," he observed, "but whoever it was, I should like him, or them, to drag a hand-cart through the State of Iowa in the month of July on exactly the same amount and quality of fare we had." 12

On July 25, the weather remained warm as the Willie Company traveled over the rolling prairie. Despite a cool breeze, many sickened and sought to ride in the provision wagons. That afternoon, the Poweshiek County sheriff stopped the

12. Chislett, “Narrative," 316. 
handcart train to search for women reportedly tied up and held against their will in the wagons. Captain Willie gave permission for the posse to search for the alleged captives. Finding nothing, the sheriff's group left the company to continue the journey. The migrants made 13 miles that day, then camped at a disappointingly poor campsite. About 30 antagonistic local denizens came near the handcart camp that night, creating a noisy disturbance, singing bawdy songs, making threats, and calling the Mormons names. Seeing the camp guards, they left without further incident.

A heavy rain fell next morning. Despite the downpour, the company slogged forward through mud and splashed through puddles. The "rather muddy" roads, in Woodward's words, made traveling difficult. Cart wheels bogged down and the drenched human teams tired as they struggled to pull their carts along. About ten o'clock, the rainfall ceased and the road slowly began to dry up. The company kept moving until one o'clock in the afternoon, then, having trekked about 11 miles, stopped for the day.

On Sunday, July 27, the company rolled out after prayers. Through the cool, pleasant morning hours, the cart wheels rolled over hilly terrain for five, possibly six miles. After two hours of walking, the company camped on North Skunk Creek so the Saints could worship and attend to practical matters such as washing their clothing. After two consecutive days of short travel, the people felt stronger and healthier.

Levi Savage noted that a "goodly number" of curious local citizens, including some "ruffians," visited the camp to see these Mormon handcart migrants and hear the Mormon preaching. One troublemaker stole a hatchet, which led to an angry exchange of words. During the afternoon and into the evening, a few belligerent strangers threatened to cause a disturbance, but when it became obvious that the Mormons would defend themselves if necessary, the intruders did not carry out their threats. ${ }^{13}$

Shortly after 7 a.m. on July 28 , the line of handcarts ascended a steep hill to begin their day. Tugging their carts along over a rolling, sometimes thickly wooded and sparsely settled country,

13. Savage, Journal, 7/27/1856. 
the emigrants soon found more steep hills to climb. Using all the strength they could muster, they walked for nine or ten miles, then halted to rest for an hour or two. As they continued, the road became hilly and rough. When they neared the town of Newton, they closed ranks. The leaders had heard rumors that the company might have trouble in Newton - a few weeks earlier the Bunker handcart company had experienced opposition there. ${ }^{14}$ To minimize confrontation, the long, strung-out line of carts concentrated into a compact column and went "fearlessly," in Savage's words, through the town. The local residents lined the street to watch them pass. They stared, but did not molest the handcarters or cause trouble. Although the Willie company camped only two miles past Newton, the night was peaceful.

The next day, there were several creeks to cross, and decayed bridges made the going difficult. The migrants tramped about 12 miles and camped on South Skunk Creek. The company clerk noted that they had several "heavy hills to ascend." Some Saints, according to Savage, were "ailing and sore footed and lame." Still, the travelers maintained a "good spirit." Henry Newman, however, decided that he was not going any farther with the handcart train. Captain Willie, who insisted on orderliness and absolute compliance to authority to keep the group moving efficiently, warned the Saints assembled at meeting that evening against the disorder that was present in the company. That night, two-week-old Selena Hurren died, the second death since leaving Iowa City. ${ }^{15}$

With fine weather on July 30, the Willie company made 810 miles before halting for a two-hour noon rest. When they set out again, the Danish hundred was in the lead. Although Captain Willie wanted the company to go only four more miles to the next creek, the Danes misunderstood the instructions and kept going beyond the intended campsite. Rather than turn the

14. John Parry, Reminiscence and Diary, March 1857-September 1867, photocopy of manuscript, LDS Church Archives, 56. John Parry captained one of the "hundreds" in the Edward Bunker company, the third handcart company to cross Iowa in the summer of 1856.

15. Selena Hurren was the infant daughter of James and Eliza Reeder Hurren. Eliza gave birth to Selena on July 15, 1856, at the Mormon camp near Iowa City. Three other daughters traveled with James and Eliza Hurren: Mary (8), Emma (4), and Sarah (2). 
Danes around and have them backtrack, Captain Willie ordered the handcart train to proceed to the next creek beyond the planned one. On they went, mile after mile, without finding a creek or suitable campground. When they reached the outskirts of Des Moines, they gave up for the night. They had traveled some 20 or 21 miles. Levi Savage wrote, "Many of the Saints were nearly overdone by the long march." 16 Because they were so near town, many visitors came, but they made no disturbance.

On the last day of July, the company got an early start, crossed the Des Moines River on a floating bridge and passed quietly through the city of Fort Des Moines without incident. ${ }^{17}$ They rested for the remainder of the morning on a small creek about a mile or two outside town. That may have been where Charles Good of Des Moines came with a generous donation. That kindly gentleman presented 15 pairs of children's boots to the company. Because he gave the shoes freely and in friendship with no ulterior motives or desire to embarrass the Mormons, the Saints accepted his charity. 18

In the afternoon the handcarts again rolled west. Despite the heat, the company covered four more miles before camping for the night. A group of men from Fort Des Moines came later that evening to harass the Mormons. A strong guard posted around the camp foiled the intruders, who only made a little noise, then left about midnight.

The goal for August 1 was to reach the town of Adel, 20 miles distant, by evening. The company traveled ten miles before halting for a rest. As they continued their march in the afternoon, the day became "very hot indeed," preventing them from making their goal, and the handcart column stopped for the night only four miles from the site of their noon rest. Regrettably, one part of the company, consisting of several elderly and infirm persons who were ambulatory but unable to help propel

16. Savage, Journal, 7/30/1856.

17. This "floating bridge" was likely a pontoon (bateau) bridge, meaning the bridge structure floated for support on flat-bottom boats, secured to each other and the river banks.

18. Willie Company, Journal, 7/31/1836; William G. Hartley and Fred E. Woods, "Charles Good's Act of Kindness and the Handcart Children," Iowa Heritage Illustrated 87 (2006), 88-91. 
the carts, walked in advance of the handcart train and did not receive word to stop. Obeying the earlier instructions, the small group tramped almost all the way to Adel, six miles beyond the point where the others had stopped. Captain Willie sent the mule team and wagon to "fetch them back." It must have been very late when the group arrived in camp after their 20-mile walk and 6-mile return ride in the mule wagon. Despite the terrible heat and the long walk, the clerk wrote, "The Saints all seem pretty well." The evening passed peacefully because "the inhabitants round were civil and obliging." 19

Before reaching Adel on August 2, the company arrived at the North Raccoon River. A crowd of townspeople gathered to watch the migrants ford the knee-deep water. Some spectators called to the women to leave the company, but the women paid no heed, pretending to not even notice the bystanders. Immediately after crossing the river, the members of the Willie company, in their wet clothing, passed through Adel without further incident.

The day tested the handcarters' ability to endure patiently. During the course of the day, the migrants walked and pushed their carts 17 arduous miles, waded two rivers and a creek, slogged through a mud hole, and climbed several difficult hills. It seems that some became cranky and grumbled. Peter Madsen noted in his diary, "There was much unrest in the company, and the bad feelings showed themselves in word as well as deed." 20 In late afternoon, the company arrived at the Middle Raccoon River and camped. Local residents visited the Mormon camp without making problems. The company clerk observed, "a good spirit prevails in our midst," the hardship apparently forgotten once the travelers settled down for the evening. ${ }^{21}$

The handcart train could not afford the time to take a whole day off for worship on Sunday, August 3. The handcarts bounced behind their human teams the ten miles to the South Raccoon River. There they rested, worshiped, bathed, and laundered for the remainder of the day. The local citizenry, interested in these

19. Willie Company, Journal, $8 / 1 / 1856$.

20. Madsen, Diary, 8/2/1856.

21. Willie Company, Journal, 8/2/1856. 
transients with their strange conveyances, visited the camp, but behaved civilly.

As usual, the bugle blew at 4 a.m. to rouse the camp on Monday, August 4. It was a beautiful morning as the carts rolled away from the campsite. Their pace was rapid, despite the hills. The wayfarers marched to Bear Grove Creek, arriving at about two o'clock in the afternoon, having walked 17 miles in five hours, minus a two-hour mid-morning break. ${ }^{22}$

Nature blessed the Willie company with beautiful weather again the next day. The long line of carts and walkers traveled to Turkey Creek, making a total of 18.5 miles, a tremendous distance for underfed people, already footsore and weary from the previous day's effort. Apparently some lagged behind, thus delaying the company. Perhaps some members complained about the demands placed on them by the handcart mode of travel, for at the camp meeting that night Captain Willie and secondin-command Millen Atwood scolded the travelers for their discontent and lack of diligence. Knowing that they needed to hurry because they had been so late starting their journey to Utah, the leaders "reproved the Saints for being so dilatory \& told them if they did not repent they would not have the blessings of the Lord \& would not get through this season." ${ }^{23}$ Seasoned veterans of the trail, Willie and Atwood knew that the safe traveling season was drawing to a close and they must speed up in spite of the hardships.

During the early morning hours of August 6, the thunder boomed, a strong wind blew, and rain poured down in torrents, so the emigrants stayed in their tents longer than usual. The cleanup after the storm, which abated about 7 a.m., delayed the company's start. Part of the camp did not get on the road

22. For the location of Bear Grove Creek and many other locations mentioned in this article, see Steven F. Faux's article in this issue. Faux's analysis of the handcart route, with towns and watercourses located along the route, and his maps help readers understand the Iowa experiences of the Mormon handcart companies. A forthcoming book by Gary Long and Lyndia Carter, In Their Footsteps: Following the Willie Handcart Company across Wyoming and Utah (to be published by the University of Utah Press) contains a chapter detailing the Iowa portion of the trek. The chapter goes into much more depth than is possible in this shorter article.

23. Willie Company, Journal, 8/5/1856. 
until ten o'clock. They traveled awhile, then took their mid-day break. Pushing on again, the company followed a new road for most of the day. The dirt road, slick because of the earlier rain, ran over hilly terrain. The slippery, muddy road, rutted and pocked by hundreds of tramping feet and cart wheels, wore the walkers down. Fourteen miles from the morning's starting point, the company camped for the night at "Jordan Creek." It had been a hard day. The company clerk noted that all were "very much fatigued." Peter Madsen worried about the health of the Danish hundred; twelve Danes were sick, two children very sick. As if Anna Jacobsen did not have trials enough, her baby now entered the world. ${ }^{24}$

After spending a cold night, the company had a better day on August 7. Splendid roads and beautiful weather made the seven-mile trek to Indiantown much easier. The company passed through town during the late morning and camped a mile beyond for their dinner. Several of the emigrants stopped in Indiantown (today's Lewis, Iowa) to buy or trade for necessary provisions stocked by the merchants there. After a twohour break nearby, the handcarters pushed on more than five miles to Walnut Creek. There Isaac Smith realized that he had left his purse, containing all his money, in a shop back in Indiantown. With William Woodward, James Oliver, and two female witnesses, Smith returned to the town. Woodward obtained a search warrant from the justice of the peace. Unfortunately, their quest failed and the money was not retrieved. ${ }^{25}$

The handcart column pulled out early on the fine morning of August 8, but the provision wagons under Savage's command waited for the return of Woodward and the mule-drawn wagon. After waiting for awhile, the wagons left. Woodward did not catch up with the company until its noon rest on an east branch of the West Nishnabotna River. Through the afternoon, the handcart train made its way 15 miles to the West Nishnabotna.

24. Madsen, diary, 8/6/1856. Don Smith's translation of Peter Madsen's diary is of great value for studying the Willie company. Madsen's detailed account of the Danish hundred's experiences adds a human perspective and an exceptionally picturesque view of the Iowa landscape in 1856.

25. Woodward, Journal, 8/7/1856. 


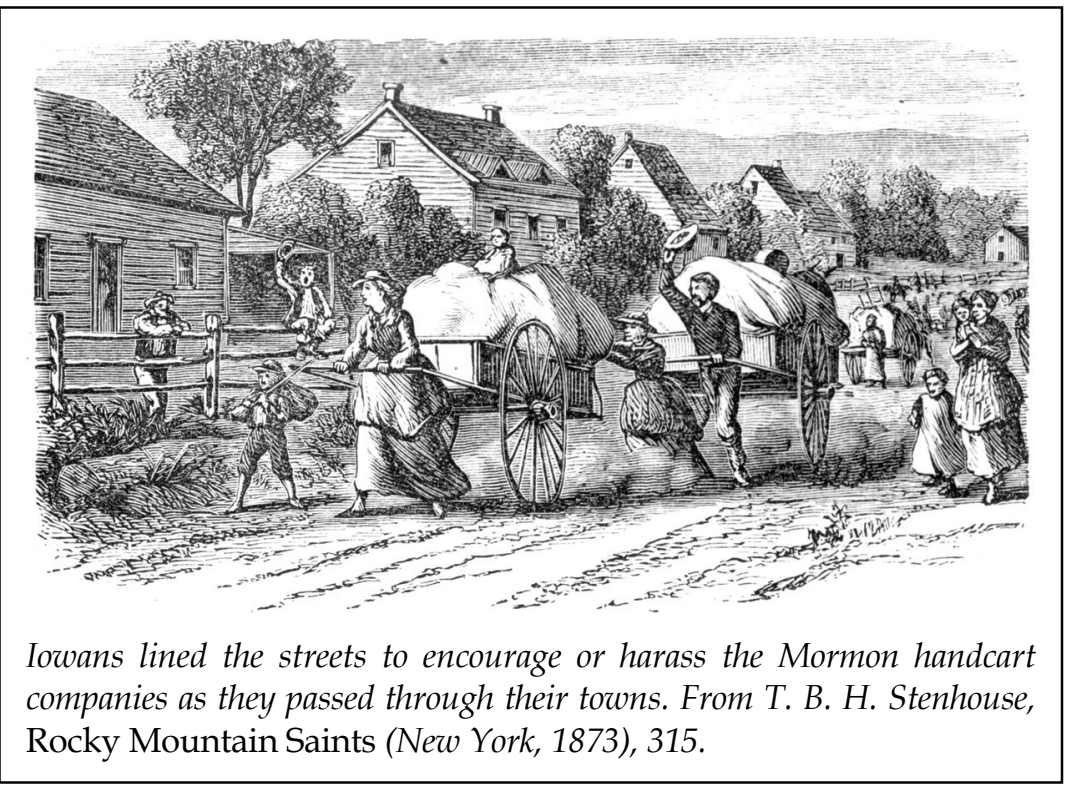

During the morning of August 9, the emigrants trekked about 11 miles through sparsely settled, rolling country, tugging their carts up high hills and holding the vehicles back while going down. At or near Silver Creek, Charles Gurner and his 15-yearold daughter and 13-year-old son left the company. Charles's wife, however, refused to drop out. After their rest and meal, the migrants moved six more miles over rolling terrain to Keg Creek. They encountered thunder and a short rain shower on the way. Likely everyone felt enthusiastic that evening in meeting because Council Bluffs lay only ten miles away. The company clerk observed, "Much of the spirit of the Lord in our midst." 26

On Sunday, August 10, the Willie company remained in camp at Keg Creek nearly all day doing laundry, cleaning up, and resting. Having failed to convince his wife to stay with him in Iowa, Charles Gurner and his children rejoined the company. At approximately 4 p.m., the handcart train rolled away from Keg Creek and headed for Mosquito Creek, nine up-and-down miles distant, where they camped. They were now only a couple of miles outside Council Bluffs.

26. Willie Company, Journal, 8/9/1856. 
The last day the Willie company spent in Iowa was Monday, August 11. At 7:15 a.m., they moved toward Council Bluffs. William Woodward had preceded the train and alerted church emigration official James McGaw that the Willie company would soon arrive. ${ }^{27}$ As the handcart train passed through Council Bluffs the townspeople "thronged" the sides of the streets and "gazed" at the long line of handcarts parading by. The majority of spectators simply stared and satisfied their curiosity. A few, however, rudely made "sport" of the Mormons and their strange mode of conveyance and aimed jeers at the lame and crippled members of the handcart brigade. To the credit of the Council Bluffs citizenry, members of the crowd reprimanded the rowdy element. ${ }^{28}$

Headed north for the steam ferry that crossed the Missouri River to the Mormon outfitting camp at Florence, Nebraska, the handcart column traveled seven or so miles, passing through a couple of small communities. James McGaw caught up with part of the troupe near a house by the road where a group of Mormon apostates and local residents started to insult the handcarters. McGaw, unwilling to tolerate the abusive criticism and bullying behavior, came to their defense. Tempers flared and he got into a fistfight, but no serious injury was done.

The Willie company intended to stop at a creek between Council Bluffs and the ferry, but the stream was dry, so they continued to the ferry landing. McGaw assisted Captain Willie with the tremendous task of getting nearly 500 emigrants, their handcarts, and five provision wagons transported across the Missouri River on the steam ferry Nebraska. The process took several hours and many crossings to complete. By evening the job was done, and the Willie company had completed its trek across Iowa.

The weeks of walking, the labor of hauling carts, and the daily hardships had undermined the health and determination

27. Mormon Apostle John Taylor, president of the church's Eastern States Mission and editor of The Mormon, a church newspaper published in New York City, had appointed James McGaw to be one of the church's emigration agents at Florence, Nebraska Territory, to assist with purchasing provisions and cattle on the frontier to supply Mormon handcart and wagon companies as they "jumped off" from Florence. See Don Smith's article in this issue.

28. Savage, Journal, 8/11/1856 
of some members of the company. These factors along with meager provisions, drudgery, the risks associated with starting so late, exhaustion, and illness discouraged about a fifth of the group. Besides those who dropped out of the company between Iowa City and Council Bluffs, others who felt they had endured enough made the decision not to resume the journey from Florence, where Mormon agents maintained an outfitting camp. Most hoped to finish the journey to Zion in the future under more favorable circumstances. Of the 500 or so who started from the Mormon campground near Iowa City, about 400 remained with the Willie company when it continued west a few days later after resting, repairing carts, and replenishing supplies at Florence. ${ }^{29}$

\section{BACK AT THE MORMON CAMPGROUND near Iowa} City, in mid-July Daniel Spencer divided the large group of emigrants who had left England on the Horizon in late May, forming two handcart companies from those passengers and others at the Mormon campground who had not joined earlier groups. Edward Martin captained one, called the fifth company, and Jesse Haven commanded the other, the sixth company. By the third week of July the emigrants still at the Iowa City camp obtained their handcarts as the workmen finished them. On the evening of July 20, Jesse Haven received notice that his company of approximately 300 must leave as soon as possible. ${ }^{30}$

29. According to the various journals written by members of the Willie company, part of the group left Florence on August 16 and camped on Little Papillion Creek, where they waited for the rest to join them on August 17. Reunited, the company again moved westward on August 18. The Willie company, now numbering 85 carts and approximately 400 persons, continued the journey under Willie's command. However, there were still five "hundreds" with the original five captains of those divisions continuing their responsibilities over fewer people.

30. Jesse Haven's daily personal diary account of the trek across Iowa (in LDS Church Archives) is the only extant contemporary account of the progress of the Haven company. A few reminiscences supplement his record. They will be cited as they are used. Although Jesse Haven captained the "sixth" company, his group was actually the fifth to leave Iowa City. This was probably an executive decision made by Daniel Spencer because of various unknown factors, 
On July 22 he moved his group one mile, then set up camp again. They did not move again until the evening of July 24, but only went two miles. The next day they stayed where they were. Ether Enos McBride, then just a child, later recalled that many grumbled about the slow start. ${ }^{31}$

On July 26, the Haven company pushed and pulled their carts three miles. The provision wagon cattle gave the teamsters a great deal of trouble, so the tents did not catch up with the walkers until after dark. While they waited for the tents, a rainstorm struck, drenching the migrants. Years later, John Southwell recalled an incident that might be the one of July 26:

Here was no sign of shelter. Our tents were rolled up in our wagons. After everyone was drenched and many were unable to move out of their tracks, the captain gave orders to pitch camp and set up the tents the best they could in the mud and as quick as possible this was done. It proved a temporary shelter for the old people and children. They were protected from the rain but they were still ankle deep in mud. At this stage of the game, the younger men displayed their heroism. Near our intended camp ground was a large patch of young willow and they attacked the willow patch with ax and pocket knives and in as short a time as possible they had enough ground covered on which we raised our tents, spread down the bedding, and then a good old farmer living in the distance gave us wood from his pile of dry willows which was soon piled up and a fire built. In the meantime the storm had spent its fury and men, women and children were soon standing and turning themselves around drying their wet and bespattered clothing. ${ }^{32}$

but likely based on relative preparedness and the fact that John Jaques, one of the leaders of the Martin (or "fifth") company, was not yet back from St. Louis, where Spencer had sent him on business. John Jaques (in St. Louis), to Orson Pratt, 7/22/1856, in Stella Jaques Bell, Life History and Writings of John Jaques (Rexburg, ID, 1978), 111-16.

31. Ether Enos McBride, "Autobiography," in Kate B. Carter, comp., Heart Throbs of the West, 12 vols. (Salt Lake City, 1939-1951), 1:81. Because McBride was a very young boy in 1856 and wrote his memoirs much later in life, he mistakenly names Edward Martin as his captain, but Martin did not take over command of his group until the two groups combined in Florence.

32. John William Southwell, "Diary of John William Southwell" [actually an autobiography written at age 79], typescript, LDS Church Archives. Southwell indicated that they laid over the next day, which is in error since the company did travel three miles on July 27. 
The next morning everything was still soggy, and the handcarters complained, blaming Haven for the missing tents. Even though it was Sunday, the Haven company moved three miles on July 27. In meeting that evening, Haven felt it necessary to call the grumblers to repentance. In his journal he wrote, "I told them if they did not scese their grumbling that sickness would get into their midst and they would die off like rotten sheep. But if they would be humble and keep united the blessings of the Lord should attend them." 33

The next day, Haven's followers again moved just three miles. Finally the company made its first long pull on Tuesday, July 29. After traveling 15 miles, the migrants encamped "much fatigued." Emma Batchelor left the company and went among the Iowans, an act that caused Haven to disfellowship, or banish, her from the company. She joined the Martin company a few days later. ${ }^{34}$

The next day's trek put nine miles behind them. The journey became too much for Robert Evans, who was in poor health. He and the elderly Sarah White, 75 years old, obtained permission to drop out of the company.

Repairs of a broken ox yoke delayed their departure from camp the last day of July. By traveling in the evening, they achieved ten miles for the day. A group of local settlers came to camp, intending to disturb the migrants, but with genial words Haven cooled down the bunch of rowdies. This may well be the situation Southwell remembered:

We came to a halt by a nice stream and in the foothills was grass for the oxen. The teams were out to feed and instantly two men started for them, cursing the G.D. Mormons, declaring they would kill every S.O. a B. of them. Captain Haven met them and in his gentlemanly way apologized and offered them pay in order to secure a night's feed for the poor, hungry brutes. This kind act on his part took them by surprise and they consented to leave them there without further trouble. The singing of the young ladies at evening service drew the attention of the kinder disposed people

33. Haven, Diary, $7 / 27 / 1856$.

34. Much confusion exists concerning Emma Batchelor. Several modern works erroneously place her in the Willie company and have her joining the Martin company in the Fort Laramie area. Haven's diary corrects the misinformation. 
and in the morning they brought butter and milk into camp and expressed themselves as being pleased with the way we conducted ourselves traveling through their country. ${ }^{35}$

The first day of August was just plain terrible. First, five people gave up the journey. Then the day grew hot and the people became hungry. They complained that their rations were insufficient. After a hard day's travel of six miles in the heat, the Moss and Hunter families sought permission to give up the journey. Haven let them stay behind. The Moss family and two of the Hunter boys later joined the Martin company.

On August 2, after being delayed by a rain shower, the Haven company tramped 18 miles, a grueling feat that drained their energy. Captain Haven noted: "some got into camp latesome did not come in at all." The trial run across Iowa was proving a trial to the runners. Fortunately, the company rested the next day, a Sunday. The heat was just too unbearable to move and they did not even hold worship services.

On Monday, August 4, the Haven company passed through Newton, where Haven purchased some tallow to grease squawking cart wheels. After traveling 20 miles, the migrants encamped late that evening. The following morning they went five miles to the Skunk River. They took the ferry across the river, although they had previously simply waded the streams. Ferrying ate up several hours, as it took 13 trips to get all the carts, supply wagons, and people to the opposite side. Still, they went another five miles before setting up camp late that night.

Hoping to make their food supply last until they reached Florence, Haven had been doling out only ten ounces of flour per person each day, giving them less than a thousand calories to work on. But the scanty allowance was causing "so many to leave me," Haven wrote, that on August 6 he decided to increase the ration to 12 ounces of flour. 36

35. Southwell, "Diary” n.p.

36. Haven, Diary, 8/6/1856. Flour was the staple in the handcart diet. Ten ounces of flour equates to approximately 875 calories; 12 ounces supplies about 1,050 calories. A few other items, as mentioned by Chislett and others, were doled out occasionally, but extras came seldom and in meager amounts. The handcarters supplemented their diet with edibles they found in nature, foodstuffs they purchased (if they had any cash or things to trade), by accepting food and milk local residents gave them, and by begging. 
Taking the toll bridge across the Des Moines River, Haven's company passed through Fort Des Moines on August 7 and camped four miles outside the city. The next day, Haven received a handout from a local settler, as had others in his party from time to time. On August 9 Haven had breakfast at the Hildreth home. Mr. Hildreth was a former Mormon; Mrs. Hildreth was still faithful to the church. Elizabeth Sermon, who likely was a member of Haven's company, remembered the kindness of the Iowans: "Some farmer[s] who lived between Iowa [City] and Florence, Neb. would take up the children that had to walk and bring them along for a few miles. Some of the farmers kindly gave the children food to eat, which I have no doubt was well received by the way it was soon out of sight." 37

August 9 was a bad day for these handcart migrants. They became "much scatered" along the road, the line of carts stretching for a great distance because many were not able to keep up. Eleven more gave up and left the group that evening after eventually reaching camp. To make matters worse, some Iowans came around camp making noise to disturb the weary travelers. ${ }^{38}$

Disturbers came to camp again the next day, slinging ugly insults and jeers. Although it was the Sabbath, the handcarters took down their tents and moved ten miles, camping near the South Raccoon River. For the next two days, the Saints traveled well, apparently without complaint or dropouts, averaging about 16 miles per day over good roads. Rain forced the migrants into camp early on August 13 after a march of only six miles.

On August 14, Haven changed the routine. Normally the supply wagons followed the handcarts so that if anyone fell behind because of sickness or extreme fatigue, the teamsters could pick them up and give them a ride. But this day, Captain Haven sent the wagons ahead of the carts, thus forcing the travelers to rely more on their own power. The company traveled nearly 18 miles and camped about five o'clock. The pleased leader wrote in his journal, "all got into camp in good season." 39

37. Elizabeth [Sermon] Camm, "Letter" written to her children, 3/16/1892, LDS Church Archives.

38. The Kirkman family - Robert, his wife, Mary, and their six sons - likely left the Haven company at or near Adel but later joined the Martin company.

39. Haven, Diary, 8/14/1856. 
Despite a delay to fix broken carts, the Haven company covered 18 miles again the next day. The 21-mile trek of August 16 was made in two parts: 14 miles to Silver Creek, then "tea" and rest, followed by another 7 miles to Keg Creek, where the company camped. While at Keg Creek on Sunday, August 17, an unidentified woman gave birth to a son. At five o'clock that afternoon, the handcarters hitched up and pulled 10 miles to Mosquito Creek, not arriving there until nearly 10 p.m.

On August 18, the company passed through Council Bluffs. Captain Haven made no mention of any trouble there. Outside of town a couple of miles, a teamster turned over one of the supply wagons while crossing a bridge. In the accident an older woman was hurt, but no bones were broken. The line of carts pushed north to the ferry that crossed the Missouri River. They camped for the night and the next day ferried across to Florence, where they camped and waited for the Martin company. After Martin's arrival at Florence, church emigration agents there relieved Haven of his command and placed the members of his company under Captain Martin's direction. ${ }^{40}$

Despite hunger, hardship, and the fact that they were too late to be crossing the Plains safely, the members of the company were eager to finish what they had begun. An example of such commitment was Thomas Durham of Haven's company. The offer of a job at the steam ferry across the Missouri River could not entice Durham to give up the journey to Utah Territory that season. Durham remembered the incident: "Met James Bradshaw the captain of the steam ferry boat across the Missouri River. Took us in and treated us like his own. Wanted me to stay with him through the winter and he would fit me up with a team in the spring to cross the Plains with. He said it was too late to cross the Plains that season." But Durham chose to ignore the warning and turned down the proposal. He would take his chances with the others of the Martin company when the two companies merged. ${ }^{41}$

40. Jesse Haven finished the journey west that fall with the Hodgetts wagon company, a Mormon wagon train that traveled near the Martin Company.

41. Thomas Durham, Reminiscence, ed. G. Homer Durham, typescript, LDS Church Archives, 15. 
Heber Robert McBride, a 14-year-old boy in 1856, later summed up his passage with the Haven company across Iowa: "nothing of intrest only hard work." 42 A 15-year-old lad in the company, Aaron Giles, who experienced hunger and sickness along with hard work, complained:

we had our Raitions served out to us which was very little. The 2 sisters never gave me vitules enough. and never gave me my full Raitions of provision. ... They never gave me enough to keep my up [sic] before I had got halfway from Iowa City to Council Bluffs I took sick with a very bad Cold which brought on the ague fever. ... I had to work and travell all the time I was sick which was a hard trial. ${ }^{43}$

Although Giles's case is remarkable, it demonstrates challenges involved with handcart travel and the restrictions of its lean budget. The hardships of the trek across Iowa tested the Saints in the Haven company, but most, even some of those who gave up temporarily in Iowa, maintained their commitment. After a few days' rest in Florence they were ready to willingly pursue the journey across the Plains and mountains to Salt Lake Valley with the Martin company.

RECORDS left by members of the Martin company chronicling their Iowa crossing are abundant and rich in detail, but only a brief summary is necessary for this composite narrative. ${ }^{44} \mathrm{~A}$

42. Heber Robert McBride, "Reminiscence," BYU Library.

43. Aaron Giles to [Mr. and Mrs. Barnet Giles], 12/3/1856, Brigham Young Papers, Incoming Correspondence, LDS Church Archives. Aaron Giles wrote the letter from Fort Leavenworth to his parents in Somerset, England, who in turn sent a copy to Orson Pratt, president of the LDS church's British Mission in 1857. Pratt forwarded the copy to Brigham Young. Aaron Giles traveled without parents or siblings from England and was assigned to help two women pull a handcart. Because he felt mistreated, he left the women and drew his rations with another man. Giles experienced many difficulties traveling across Iowa and Nebraska Territory and dropped out about a hundred miles east of Fort Laramie. Some U.S. soldiers found and took care of him.

44. Diaries and journals are as follows: Joseph Beecroft, Journal, LDS Church Archives (Beecroft's 1856 journal is wonderfully detailed; unfortunately, the information about the Martin Handcart Company ends when illness caused Beecroft to quit the company at Des Moines on August 14, 1856); John Jaques, Diary (edited by his great-granddaughter), in Stella Jaques Bell, Life History and 


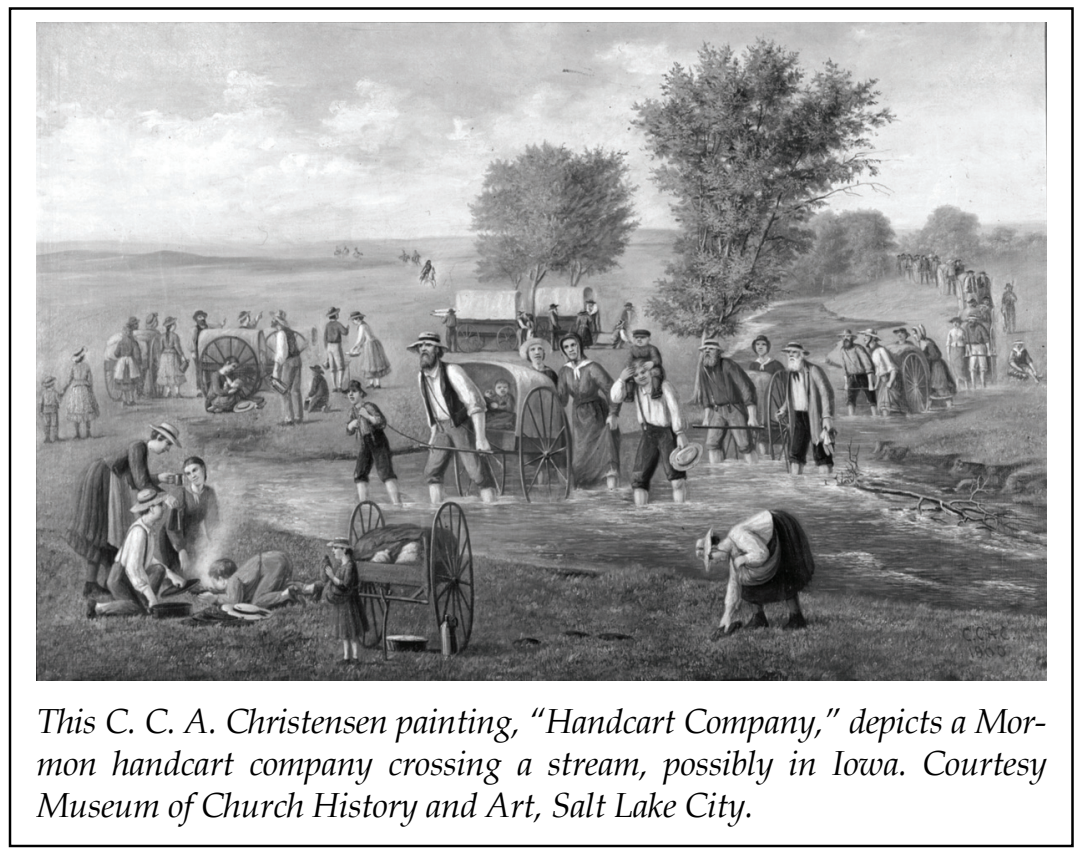

main focus here will be on this company's interaction with the people of Iowa as they traveled. The places, terrain, heat, dust, rain, hunger, sickness, occasional deaths, and terrible fatigue were much the same as experienced by the Willie and Haven handcart companies.

Starting on July 25, the 300 or so people assigned to Captain Martin made a series of little moves over the next several days. Years later Albert Jones wrote delightfully of the first creek crossing after leaving the camp near Iowa City. A spry 50-year-

Writings of John Jaques (Rexburg, ID, 1978), 118-27 (the holograph was lost in the flood caused by the breaking of the Teton Dam in Idaho); James Godson Bleak Sr., Diary, 1854-1860, holograph, LDS Church Archives; William Lawrence S. Binder, "Biography and Journal of William Lawrence S. Binder," photocopy in author's possession (apparently Binder copied his 1856 handcart diary into the autobiography he wrote in later years, date unknown); Samuel Openshaw, Diary, in An Enduring Legacy, ed. Daughters of Utah Pioneers Lesson Committee, 12 vols. (Salt Lake City, 1981), 4:197-208. The most useful reminiscences are John Jaques, "Some Reminiscences," in The Salt Lake Daily Herald, 12/1/1878; and Josiah Rogerson, "Martin's Handcart Company, 1856," in Salt Lake Herald, 10/20/1907. Other reminiscences will be cited as they are used. 
old woman from Scotland led the way for the females in the company, he remembered:

some of the Girls quite a number, were in a great quandary as to how to get over: in a twinkling this Sister had her Shoes and Stockings in her hand, with skirts tucked up daintily to her knees, was in the Creek with a hop and skip - saying "come bonny girls let me show you the way and dinna be afraid of showing your legs for I ken you will wade more than once on the journey." 45

They were not really on their way until the afternoon of July 31, when they traveled about five to seven miles in about five hours. Sarah Loader reportedly remembered that it was "a glorious day to be on the move. It was like going to a picnic after the long tiresome wait in the heat." It may have seemed like a picnic to Sarah, but to Joseph Beecroft it was "much labor." 46

The next day the Martin company moved only six or so miles although they traveled from nine or ten in the morning until about seven in the evening, with a long rest at midday. Progress was slow over sandy roads, the weather intensely hot. For Beecroft it was a difficult day. He felt fatigued and faint, his shirt "quite wet with sweat." For others who were younger or had better health or more stamina, the labor was less arduous, and high spirits and anticipation tempered the hardships of the first days. Samuel S. Jones remembered, "As we journey[ed] through Iowa with our novel conveyances we assumed somewhat of a jaunty air. The handcarts were all new and we merrily sang as we traveled along." 47

The morning of August 2 a heavy thunderstorm hit, delaying departure and making travel over wet roads laborious, but cooler in contrast to the previous day. Then the weather turned oppressively hot again during the days that followed. The long line of exhausted handcarters stretched out on the road, the people moving at their own pace, some lagging far behind.

45. Albert Jones, Reminiscences and Journal, holograph, BYU Library, 38.

46. Interview with Sarah Loader Harris Holman, at age 92, regarding her handcart experiences in Ray J. Davis, Autobiography of a School Teacher (privately published, 1967), 99-100; Beecroft, Journal, 7/31/1856.

47. Beecroft, Journal, 8/1/1856; Samuel S. Jones, in Provo Daily Inquirer, 7/6/1892. 
Amazed Iowans recognized the difficulty of this novel mode of travel. John Watkins recalled,

While traveling through the state of Iowa ... the dust of harvest weather was four or five inches deep. The sun's rays poured down on our heads, the perspiration and dust streamed down our faces and got into our throats, choking us so that we could hardly breathe. We were tantalized by the people coming out of their houses to tell us, 'That is a damn hard way to serve the Lord.' 48

The Martin company camped near Marengo the night of August 3. Marengo residents visited the handcarters in their camp two or three miles southeast of town and proved as troublesome to the Martin company as they had to the other handcart groups. Joseph Beecroft noted that these strangers annoyed them and "hung after Sister Elizabeth Walker. Some were rather intoxicated and came out in a threatening attitude and with threatening language." John Jaques also noted the unfortunate incident with some local rowdies: "Two wagon loads of rough men came to our camp from Marengo with the intention of creating a disturbance, but they were unable to and went away in a short time shouting and yelling." These ruffians, according to Jaques, gave the migrants a sample of "western profanity, oaths and 'by Gods' rolling from their tongues about as frequently as other words, and with much more gusto." 49 To avoid further trouble, the Mormons took a fork in the road the next day to bypass Marengo.

The road they traveled on August 5 led through the woods. The emigrants dodged stumps that had not been removed when the road was cut. Unfortunately, the Openshaw cart ran against a stump, breaking the wheel off. The Openshaws piled their belongings in a wagon, tied up the cart and wheel with rope as best they could, and caught up with the company at Bear Creek. The road also caused another cart's axle to break. ${ }^{50}$

48. John Watkins, reminiscence quoted by his daughter Mary A. Schaer, in A Brief History of the Pioneer John Watkins (privately published, undated), 24.

49. Beecroft, Journal, 8/3/1856; Jaques, Diary, 8/3/1856, in Bell, 120; Jaques, "Some Reminiscences," Salt Lake Herald, 12/1/1878.

50. Openshaw, Diary, 8/5/1856; Jaques, Diary, 8/5/1856, in Bell, 120-21. 
Apparently men as well as carts broke down. On August 6, for instance, Samuel Openshaw felt so weak he could not pull the cart for his parents and the children; he had to switch places with his father, who normally drove a provision wagon. Joseph Beecroft felt fatigued, feverish, and in pain. Francis Webster was ill much of the way across Iowa. He remembered, "I had the diarrhea all the way from Ioway City to Florence so bad that I have sat down on the road and been administered to by the Elders and got up and pulled my hand cart with renewed vigor." 51

Illness forced the Josiah Rhead family to drop out August 8 near Newton. When Rhead collapsed, the company had gone about 15 miles, and the day's travel was not yet finished. Josiah was extremely ill and exhausted, unable to walk another step. His wife, Eliza, with two children, Edward, 5, and the baby, Eliza, 1, could not possibly carry him on the family's cart. Because they were not too far from a settlement and it was absolutely impossible for Rhead to continue, the Martin company abandoned the family and took the handcart because it was church property. Edward, the boy, wrote of the experience more than 50 years later:

When about 100 miles on the way Father was taken very sick, when our handcart was taken from us and we were left on the Iowa praires with but one old tin box which contained our whole effects of food and clothing. Father was so ill that Mother had to carry him for about three or four miles on her back to the nearest town, then called Newton.

Eliza got her husband to a farmhouse, where the farmer provided him with shelter and care. A few years later when health and financial circumstances permitted, the family was able to complete their journey to Zion. ${ }^{52}$

51. Openshaw, Diary, 8/6/1856; Beecroft, Journal, 8/6/1856; Francis Webster, Reminiscences, 1848-1881, 9, microfilm of holograph, LDS Church Archives.

52. Edward H. Rhead to the Handcart Veterans Association, 11/21/1907, Coalville, Utah, in the Handcart Veterans Scrapbook, LDS Church Archives. Additional Rhead family records are in the Silas LeRoy Collection, BYU Library. From these accounts it seems that the Rhead family was with Edward Martin's company. No contemporary complete list of names is extant for either company, making it impossible to say precisely who was in which company in Iowa, although many names can be ascertained in various pieces of evidence in extant documents such as this letter. 
Josiah Rogerson remembered people from Newton visiting the Martin company camp a couple of miles beyond Newton. "They came to our camp and entreated of us earnestly and sincerely not to go any farther on account of the lateness of the season, and seemed to be very anxious in wanting us to stop. That they could and wood furnish us employment for a number of our able bodied men, etc., but we were westward bound, and none stopped." 53

Despite the great faith and determination of nearly all in the Martin company, there were some dropouts who felt handcart travel was not for them. Twelve-year-old Zachary Robinson was one. After listening to the enticements of a rich man on the road during a rest break, Zachary was "decoyed" away. The man was taking a large machine to where he lived farther west and likely offered the boy a job. Zachary disappeared. Early the next morning, August 9, his father, George Robinson, refusing to leave his youngest son, left his family and set out searching for him. Although he later found the boy, neither the father nor the son went on to Utah. The mother, Margaret, and their two daughters continued west with Captain Martin's company. ${ }^{54}$

The company experienced its first recorded deaths since leaving the Iowa City campground as it camped by the South Skunk River. Daniel Normington, aged one year and eight months, perished of diarrhea on August 10. The next morning John Wright, 42, died of ague and fever and was buried at the same camp. 55

William Binder described the company's reception at Des Moines on August 12: "while crossing the river the inhabitants ridicule our Mode of travel and made some very unkind remarks about us. But we gave them to understand that we were fulfilling the commandments of God and while they scoffed the saints rejoyced." 56 However, the Beecroft family received kind treatment there when they found it impossible to continue their journey.

53. Rogerson, "Martin Handcart Company, 1856."

54. Beecroft, Journal, 8/9/1856. Beecroft calls the lad Zachary, although the passenger list from the ship Horizon says George Robinson, like his father.

55. Binder, Journal, 8/10-11/1856; John Jaques' list of deaths in Bell, 306. Jaques inadvertently lists both deaths as August 12.

56. Binder, Journal, 8/12/1856. 
After leaving Iowa City in July, Joseph Beecroft grew increasingly weak, his journal chronicling his sufferings and decline. He became ill, the symptoms indicating severe ague or malaria. With each day his struggle to keep going became harder. As the Martin company neared Des Moines, Beecroft was too weak to pull his cart. Men attached his cart to a wagon, and Joseph tried walking, but staying on his feet became impossible. One of the leaders ordered him into a wagon to ride. About ten o'clock the company entered Des Moines. Beecroft, a bit rested and hoping to purchase in town some medicinal gin to ease his malady, had walked with his son ahead of the main party. He left his son and hurried off to find a liquor shop, giving his son instructions to tell his wife and the teamster to stop and wait for him. The boy gave the message to his mother, but failed to tell the teamster, so the company moved on through town without him.

Near total collapse and realizing that it was impossible for him to go on, Joseph Beecroft resolved not to leave Des Moines until he felt better. Reunited with his wife and son and in horrible pain, he sat down in a wood yard and left himself and his family in God's hands. A number of curious people stopped and asked questions, but none gave assistance. The situation seemed gloomy. Rather than stay outdoors all night, Joseph's wife and son went in search of lodgings. A kind-hearted man, Tudor Beall, gave Joseph and his family accommodations and would not accept money for either food or lodging. Some of Beall's servants protested against taking care of Mormons, but the good man and his wife told them they could quit, but the Mormons were staying. Some men from the Martin company came back with a cart for Joseph, but his wife informed them that he was too sick to be moved. Understanding the situation, they left their blessing and returned to the company. The Beecrofts' personal possessions were left at a post office four miles beyond Des Moines.

The family stayed in the city. Joseph slept until noon, but remained sick with diarrhea, shivering, pain in his limbs, and extreme weakness. Their kind benefactor provided them with a house, food, and medical attention during Joseph's recuperation. Within a few years, the Beecroft family was able to finish the 
trek to Utah Territory, but with oxen and a wagon instead of a handcart. 57

Before reaching the town of Adel on August 14, the Martin company forded the North Raccoon River, which was about 20 inches deep. ${ }^{58}$ Stream and river fordings, such as this one, supplied the ruder residents along the handcarters' route through Iowa an opportunity to ridicule the migrants. Crossing streams was anything but pleasant for women in long skirts and petticoats. Yet cross them they must, and frequently. Modesty was compromised in the process. Such a show was quite interesting and amusing for some male settlers scattered across Iowa. John Watkins wrote in disgust of such "young hoodlums," who would "go ahead of the company to the next river or creek to ridicule our wives and daughters who had to raise their dresses out of the water to wade the streams as there were not many bridges in those days." 59

The Martin company picked up the Kirkman family at Adel. ${ }^{60}$ Robert Kirkman, his wife, Mary, and their six young sons, the youngest born at the Iowa City camp, had dropped out of the Haven company and were at Adel when the Martin company passed there several days later. After being encouraged by members of the Martin company to join them, Robert Kirkman decided that his family would finish the long trek to Zion that season despite their misgivings. John, one of the sons, later recalled, "My Father had been offered a position for the Winter so decided to stay in Iowa until the Spring, but the Saints came so many times to see my parents and urge them to travel

57. Beecroft, Journal, 8/12/1856. The first journal entry to indicate Joseph Beecroft's illness was August 1. From that time, the entries record in detail his increasingly debilitating condition. Beecroft, when well enough, continued to keep a journal after his decision to remain in Des Moines, allowing researchers to follow his story.

58. Openshaw, Diary, 8/14/1856; Binder, Journal, 8/14/1856. The Martin company negotiated two major river crossings that day, the North and South Raccoon. Although all had to walk through the North Raccoon River, men dragged the carts across the South Raccoon while the women and children crossed on a footbridge.

59. John Watkins, quoted in Schaer, Brief History of the Pioneer John Watkins, 24.

60. Openshaw, Diary, 8/14/1856. The transcript of the journal spells the family name as Thirkman rather than Kirkman. 
with them, so after talking it over with Mother he said, 'Well, we'll go with them live or die.'" As it turned out, Robert and his infant son did die, both on the same night in November at one of the Martin company's camps in the Sweetwater Valley after leaving Martin's Cove in what is today Wyoming. They were buried together, the baby cradled in his father's arms. Mary and their five other sons, one of whom had badly frozen feet that impaired him for life, made it to Utah Territory. ${ }^{61}$

The sixteenth day of August presented a new trial - too little water. During the three previous weeks, too much water had often been a problem, with sudden rainstorms or many streams to cross. But this day there was no water to quench their thirst or cool them. Covering 17 miles in about 6-7 hours, the handcart brigade traveled through dry, sparsely settled country. They could carry only a little drinking water, and that was soon used up. James Bleak tersely recorded, "Travelled all day without water," and Samuel Openshaw complained, "The day being hot we felt the want of water." The handcarters finally refreshed themselves when they camped west of Mud River, not far from the little town of Dalmanutha (now a ghost town). ${ }^{62}$

As time was running out on them, the Martin company rushed toward the Missouri River, covering more than 17 miles on August 17. Samuel Openshaw noted that they "travelled all day without seeing an house or even a tree except a few at a distance, nothing but prairie grass to be seen." 63 Water was again scarce, except for the drenching thunderstorm that hit them that afternoon almost immediately after they pitched their tents on Turkey Creek near Morrison Grove.

During each of the next few days the company pushed grueling, long distances in excess of 20 miles. Illness and physical strains increased. Langley Bailey became seriously ill, likely in

61. John Kirkman, in his biography of his mother, Mary Lawson Kirkman, in Pioneer Histories, Camp Springville (1936), 1:157-60, located in the Daughters of Utah Pioneers Museum, Springville, Utah. A slightly variant version is John Kirkman's "Sketch of the Lives of Robert Kirkman and Mary Lawson Kirkman and Family," read by him at a Springville Daughters of Utah Pioneers meeting, 3/13/1930 (and now held by the museum).

62. Bleak, Diary, 8/16/1856; Openshaw, Journal, 8/16/1856; Binder, Journal, 8/16/1856; and Jaques, Diary, 8/16/1856.

63. Openshaw, Diary, 8/17/1856. 
western Iowa, although his reminiscence does not name a specific place. He recalled, "This mode of travel proved too much for me. I was taken down with hemerage of the bowels. I was unable to walk, had to be hauled on Bro. Isaac J. Wardle and my brother's cart." In painful agony he bounced along the trail in a cart by day and groaned in his bedding at night. ${ }^{64}$

The Samuel and Elizabeth Read family became separated at the Keg Creek camp in southwestern Iowa, August 20-21. Walter, their eight-year-old son, disappeared. Not until much later would his parents learn what happened. Lured by the tempting offer of a pony, Walter ran away with two men to work on their farm. Elizabeth and Samuel, not knowing what had become of their son, decided that Samuel and their older son, 14-year-old Samuel Milford, should remain in Iowa to search for Walter. Elizabeth and the two daughters, Thisbe, 9, and Alicia, 15, would go on with the company. The couple hoped that the missing boy would soon be found and Samuel and both boys would catch up. Unfortunately, they did not. George eventually tracked down and retrieved his stray child, but the search took months. Meanwhile, the older son became separated from his father. The family was at last reunited in Utah Territory, but only after several years and a number of trips across the Plains, in both directions, by various family members. ${ }^{65}$

With instructions from their captains to keep close together, the members of the Martin company passed through Council Bluffs the afternoon of August 21, apparently without incident. The emigrants traveled north up Pigeon Creek seven or so miles and encamped at "Missouri bottom." 66 The next morning they tugged their carts the last four miles west on a sandy road to the ferry that crossed the Missouri River to Florence. The crossing took six hours to complete.

64. Langley Allgood Bailey, Reminiscences and journal, ca. 1920-1929, 5, microfilm of holograph, LDS Church Archives.

65. "Walter Pyrimus Read," and "Alicia Read Arnold," in Andrew Jenson, comp., Latter-day Saint Biographical Encyclopedia, 4 vols. (1901-1936), 2:493, 494; May S. Arnold, "Samuel Read Family," in Carter, ed., Heart Throbs of the West, 6:370; Elizabeth Read Black, "Samuel George Read and Family," ibid., 5:269.

66. Josiah Rogerson, “Martin Handcart Company, 1856," Salt Lake Herald, 10/20/ 1907. 
While waiting his turn, Samuel Openshaw climbed a hill and reflected on the journey across Iowa:

Every place we came through we were admired by the people very much, some looked upon us as if we were divine; others, who were old apostates, came with all the subtlety of the devil and all the cunning gained by their own experience, trying to turn the Saints to the right hand or to the left, but thanks be to God, but few or none adhered to their advice. ${ }^{67}$

With their arrival at Florence on August 22, Iowa was behind them. Josiah Rogerson later summed up the first segment of the long handcart road to Zion: "Nothing of any great consequence occurred on this trial trip of our handcarts, and ourselves, except that we had some excessive hot weather, very dusty and badly cut up roads and [some] deaths occurring." Completing that portion of their long journey to their Zion required physical and emotional stamina. John Jaques called the work of pushing and pulling handcarts a "killing business." Some, like Jaques, found pulling handcarts from Iowa City to Florence a trial of endurance, but Isaac Wardell, then 21 years old, later opined, "We did not have difficulty on the road." 68 Despite his assessment, the emigrants had endured hardships. Some got stronger and grew accustomed to the work as they went; a few became sick, so sick they had to end their journey in Iowa, either because of death or total inability to travel. A small minority, particularly young boys, grew discouraged with the drudgery and the lack of sufficient food and dropped out. However, the vast majority overcame the personal discomforts and trials inherent in handcart travel.

They ignored the ridicule, warnings, and advice of the local residents along the road, and kept walking west. Samuel S. Jones remembered words of sympathy and caution from the Iowans: "As we passed through the different towns in the state of Iowa till we came to Council Bluffs, the inhabitants would come out and look wonderingly at the novelty of the spectacle

67. Openshaw, Diary, 8/22/1856.

68. Josiah Rogerson, Autobiography, in "Autobiographical Sketches of Beaver Residents," LDS Church Archives, 23; John Jaques, "Some Reminiscences," Salt Lake Daily Herald, 1/19/1879; Isaac Wardle, Autobiography, typescript, in Ray Olsen, "Family Histories," BYU Library. 
we presented and in many cases plead with us not to go on, urging two important arguments: first, we were too late in starting; second, our conveyances were too frail for the journey. But in no case thus far were their arguments of any avail; the watchword was onward." 69 Except for a very few cases, extreme illness seems to have been the only thing that could convince Martin's Zion-bound travelers to give up the journey.

AFTER HEARING of the handcart companies' arrivals in Florence, Apostle John Taylor, president of the church's Eastern States Mission, expressed his feelings about the handcart plan:

It is exceedingly gratifying for us to learn that the hand-cart system is so successful, and that the parties engaged in it are in such good health and spirits. ... We had, as we expressed at first, considerable apprehensions as to the feasibility of so many women and children adopting this mode of transit, and the principal relief, to our mind, was, that in the event of sickness, weakness, or any other impediment, they would, for the first part of their journey, be in the neighborhood of inhabitants, where they could either rest or stay, according to circumstances; and we considered that as the distance from Iowa City to the city of Florence ... was about 260 or 270 miles . . . they would have fairly tested their strength and the applicability of the hand-cart system, as it was our opinion that this would be the heaviest part of their journey. We are, therefore, exceedingly glad to find that they are succeeding so well, and are in the enjoyment of such good health and spirits. ${ }^{70}$

Most of the members of the Willie, Haven, and Martin companies chose to stay the course to Utah by handcart; but some, weighing their individual and personal circumstances, decided to stop in Iowa or Nebraska until they could better finish the journey. About a fifth of the Willie company either dropped out in Iowa or chose to stay at Florence. Several from the Haven and Martin companies left those companies during the Iowa crossing. Those who stayed behind, including ones who had legitimate

69. Samuel S. Jones, July 24 celebration speech, recorded in the Provo Daily Enquirer, 7/26/1892.

70. John Taylor, "Hand-Cart Emigration," The Mormon, 9/13/1856. 
reasons for doing so, received some heavy criticism and censure for their choice. However, Apostle Taylor understood their reasoning and accepted their choice to wait for another opportunity to finish what they had started:

We see by some remarks of our correspondence a disposition to reflect upon those who have tarried; this may be correct, in some instances, but it is not well, in such cases, to be too censorious; all men and women do not possess the powers of endurance alike; and where people find their bodily strength give way, we should not blame them for tarrying, they have a legitimate reason for so doing.

We are told, indeed, to hasten to the mountains as fast as circumstances will admit; but we are not told, at present, "to tarry not in all the plains lest we be consumed." We therefore say to those whose circumstances or lack of bodily strength may have constrained to tarry for a while: Attend to your duties, fear your God, and live your religion, and in due time you shall go to Zion; and all shall be well with you; for although it is exceedingly pleasant to be swift in the race, and strong in battle, yet, the "race is not always to the swift, nor the battle to the strong." 71

When the handcart companies ferried across the Missouri River, they completed their trial run across Iowa. Most of the migrants had finished it successfully, some had not, but the Iowa trek was now part of each one's history. James Loynd, summing up the trial run as a learning experience, later wrote, "The emigrants learned many lessons regarding this mode of travel which were of great value to them later when they were hundreds of miles from civilization." 72 They learned to cope with pulling handcarts over many kinds of terrain and to repair the carts when they broke down. They learned to bear the burdens of hunger, exhaustion, sickness, and unpleasant weather. They developed the strength, stamina, and willpower to keep going, or they realized their limitations and quit.

Although some Iowa residents harassed and ridiculed the emigrants, many others treated them with kindness, generosity, and sincere concern. But now the taunts, the advice, and the kindhearted acts of the Iowans were behind them. Once on the west side of the Missouri, the Mormon handcart pushers and pullers

71. Ibid.

72. James Loynd, “Account,” 11/28/1926, LDS Church Archives. 
pullers were no longer rehearsing for the big trek across the Plains to Zion. Ready or not, the thousand-mile journey stretched out before them, and they were running out of time. Real drama lay ahead in the seemingly endless, empty miles of Nebraska and in the wretchedly frigid winds and snow of Wyoming. ${ }^{73}$ Despite the hardships, the hunger, the sickness, and the sweat and toil of crossing Iowa, the trial run was mild compared to the trials they had yet to face and endure, as more than 200 of them would die before the Willie and Martin companies, aided by rescuers, finally reached Zion.

73. In 1856 the states of Nebraska and Wyoming did not exist. Nebraska Territory stretched far into the present state of Wyoming from the east. Parts of western Wyoming were in Oregon and Utah territories. 